\title{
Youth in Extremely Difficult Life Situations
}

\author{
Zorc-Maver Darja \\ Full Professor \\ Faculty of Education \\ University of Ljubljana \\ Ljubljana, Slovenia
}

\begin{abstract}
The originality of this scientific study is in that it shows the importance of biographical research for a successful re-socialization of children/youth with difficult life experiences. It presents a qualitative research that was carried out recently and encompassed youth in difficult life situations, and it pleads for a pedagogical relationship based on individual biography and empowerment, resources and participative role of a young people in his/her own help-planning.
\end{abstract}

Keywords: biography of adolescents, motivation, empowerment, residential care institutions

\section{Introduction}

Changes in modern society are reflected in people no longer being bound to traditionally-defined forms of life. Shaping one's life is becoming more open, depending on the individual, who becomes the director of his own life's course (Beck 1986). The question of biography as the formation of an individual life is today becoming a constitutive element in it. Fulfilling pre-existing social and life patterns is no longer at the forefront; its place has been taken by the shaping of one's own life, where the individual seeks the purpose and goals of his own life, while constantly striving for a balance between conformity on the one hand, and personal self-assertion on the other (Bitzan, Bolay, Thiersch 2006). New demands made on the economic, consumerist and social life of an individual require the development of new patterns of coping with difficulties; the individual is no longer able to construct his biography on the basis of pre-existing traditional institutionalized patterns. In the post-modern age, biography is becoming a conglomerate of different types of experiences of different life situations; these the individual constantly re-interprets according to his or her situation in life. In constructing these interpretations, the individual uses his imagination, dramatization, as well as other defence mechanisms of suppression and rationalization.

In terms of research concerning residential care institutions, biographical research remains largely unexplored in our field. The following presentation will attempt to present the theoretical and methodological foundations which warrant the need for such research in the field of the re-socialization of children and adolescents facing social integration difficulties. Understanding an adolescent and offering help requires an "internal perspective" (Bitzan, Bolay, Thiersch, 2006) of the subject - his views, resources, problems with coping with difficulties and the subjective processes of internalizing help.

Our starting point is the thesis that the biographical reconstruction of social reality serves as the basis for understanding and planning the process of help; it represents the foundation of an effective aid. In the focus of the research are the adolescent's subjective experiences and the manner in which he experiences things. This type of research offers a variety of insights (Schefold 2004). These are the following:

1. The recounting of life stories provides an insight into how a certain "case" came into being; this involves deepening our understanding of the adolescent's situation as well as gaining insight into the story itself. In this way, we can come to understand individual meanings, manners of feeling and the process of sensemaking.

2. The stories always include the social and institutional contexts in which the life story took place, thus they provide insight into the socially-conditioned dimensions of one's situation in life, including ethical and gender identity. 
In this way, biography represents a leading concept for the scientific reconstruction and thematization concerning the factual formation of the adolescent's life within the framework of the life course (Schefold 2004).

The process of help should be based on "communication about biography" (Schefold 2004), beginning with the resources rather than the deficits of the individual, while at the same time making it possible for the adolescents to become aware of their own needs and motives as this is the only way to achieve successful re-socialization through participatory help planning.

Social as well as expert groundwork supports biographically-oriented research in the field of social pedagogy. Researching the users, their views and experiences, brings to the foreground the question of the biographical competence and the subjective reshaping of the expert help on offer. Many research results (Daigler, 2008, Glinka, 1998) confirm the thesis that for adolescents, professional help becomes genuine socialization and educational assistance only when it enables the adolescents to have different experiences than they have had thus far, when it supports them in expressing their own needs, establishes new and different patterns of facing situations in life and supports them on their way to achieving a desired "normal biography". Telling and explaining one's own story to others has an added significance for marginalized groups: it enables them to leave behind the negative self-image, which they acquired through the many negative experiences of discrimination, social exclusion and violence. The significance of narration lies not only in the course of life, but also in the social construction of reality, where on the basis of narrating past events, the individual also establishes and seeks future ways of living (Keupp 2006). Biography always also means looking to the future. In this way, the narrator becomes the producer as well as the product of the story, which changes together with the altered perspective of looking at the past (Herriger 2002). Understood in this way, biography becomes more than just a diagnostic instrument; it enables the narrator to re-construct the continuity and discontinuity of his life's path and in looking back, experiences his own self-worth, coherence and the sense of his own strength (Herriger 2002).

\section{Methodology}

The research which we are currently conducting (2008-2011) is based on a qualitative research of help effectiveness in residential care institutions consists of the life stories of 10 adolescents ( 8 boys and 2 girls), aged between 19 and 25, who have lived in juvenile educational and correctional institutions for at least three years. It focuses on the following cognitive interests:

1. Shedding light on the biographical importance of the life stories of adolescents in extremely difficult conditions of socialization. We are interested in how these young people explain and experience their life's path, and what they want to make of their lives.

2. Researching how adolescents experience the help of professional experts, how they are able to integrate it into their existing biography, and to what extent such help can provide new opportunities for learning new patterns of coping with problems, relationships and creating a different life biography. Particular stress will be paid to the significance of participation and the level of input they are allowed and enabled to have by institutional structures and experts within such institutions when taking part in decision-making on different levels of providing help.

\section{The significance of life stories}

In the reconstructions of life stories provided by the adolescents in residential care institutions, violence, neglect and separation often have a central role in the biography - and it is precisely the reconstruction of these experiences that enables them to process and normalize them. The adolescents included in the research were faced with experiences of some sort of rift early on - arguments, the death of a parent, alcoholism and aggression are the types of experiences they were faced with on a daily basis. They can envision their future life paths and wish first and foremost for a 'normal biography': education, employment and family.

Straining life situations that young people in residential care institutions are faced with often lead to feelings of powerlessness, lack of prospects and limited possibilities for participation; therefore, one of the central goals of help is to empower the adolescent, and this is closely connected with participation. Despite many experiences of vulnerability in the biography of an individual, these are not emphasized in the pedagogical help plan. The focus is mainly on the coping-with-difficulties strategies, learning processes and those experiences which offer new prospects for better opportunities in life (Herriger 2002). Of course this does not mean that the real difficulties are being ignored. However, it is important that the self-image of the adolescent is not being built upon his problems and deficits, but rather on the categories of his/her capabilities. 
Both participation and empowerment call for a professional attitude, which should be reflected anew during every intervention; it means giving every individual time, taking him, his biography and his problems seriously, and knowing how to sense even what the individual is unable to express. Empowerment calls for a professional attitude that strives for expert psychosocial work that is not overly technical, and signifies a process that enables the user to construct (personal, organizational, community) resources, which enabled him to establish more control over his life and the achievement of his goals. In order for experts to utilize the host of existing and potential resources, the relationship between the expert and the user must be based on equality and participation. The necessity of having faith in people's capabilities (even though they can have substantial problems and deficits in certain areas) and the development of capabilities through cooperation, denote the essential underlying attitude and the altered perception of social problems that a professional expert must develop within himself if he wants to encourage and develop the processes of empowerment in different fields (Stark 1996).

Throughout their lives, adolescents in juvenile educational institutions have faced many experiences of social exclusion and social vulnerability, which is why they often do not have at their disposal social and cultural capital that would enable them to achieve a higher level of social inclusion. If we want these adolescents to be able to exercise their legal rights, then we must establish a type of social climate in residential care institutions, where an adolescent will feel like an equal partner, responsible for the fulfilment of his interest.

This type of research signifies a move away from forms of assistance aimed predominantly at narrow definitions of deficit, clichéd and standardized help, and towards a more flexible and individualized form of aid. The socioethical goal of these forms of assistance is to re-establish the autonomy of the users' way of life. Biographical research broadens the horizons and encourages self-reflection both in the experts and the users alike.

\section{Styles of coping with difficulties and help experiencing}

To solve their problems, the adolescents have developed unproductive patterns of problem solving, ranging from aggression to alcoholism and drug addiction. They view their stay at the institution as positive, although for the majority, their arrival was a severe shock connected a certain amount of fear and opposition. To them the institution primarily represents a different type of interpersonal relationships - they particularly stress their relationship with their care worker. A social worker who sticks by the adolescent, who is always available and who understands, one who takes his job seriously - these are the qualities that mean a lot to the adolescents. Juvenile educational facilities also present a new type of learning environment for the adolescents, one where they have acquired various kinds of competence. They were able to arrange many but not all things with their care worker (for example, lessons were a fixed part of the daily routine). Research in the field of deviant behaviour in young people has shown that such behaviour always also presents the coping strategy and behaviour present in critical life situations (Böhnisch, 1999). Adolescents who had not acquired social and communicative competence, empathy and self-control that would help them in critical moments to develop the resources for norm-conforming problem solving in their social environment (Böhnisch, 1999), in their stead develop the ability to react at any cost, even if it means breaking the norms.

These findings are based on the coping concept developed in stress research, which shows that in a stressful situation, the body reacts on its own in order to re-establish balance. This does not always signify health; it can entail hyperactivity, depression, illness etc. Problem children and adolescents are generally children and adolescents under stress (Böhnisch, 1999). When it comes to the concept of selfhood, it is the liberated driving force of self-preservation, rather than self-control, which prevails in critical situations. The affected sense of selfhood manifests itself differently according to gender: boys tend to channel their deviant behaviour externally, while girls internalize it. The re-socialization of an adolescent's behaviour is only possible by establishing a pedagogical relationship with an adult outside the family unit. These are adults who find the adolescents important, to whom their personal development and biographical identity are important. In their interviews, the adolescents have pointed out their relationship with the care worker, who is always available to them and who understands them even when they break the rules, as an important aspect to how they experience provided help. Adolescents require a safe space where they can experience their need for self-assertion, while at the same time being set boundaries without making them feel depreciated (Böhnisch, 1999). 


\section{Conclusion}

The participation of adolescents in planning the course of help plan and the course of their daily lives, is the fundamental factor of re-socialization. It is based on empowerment, the improvement of self-image and the gaining of self-confidence, all the necessary conditions for brining about a change. In this way, participation encourages intrinsic motivation in the adolescent and the ability to cope with life's difficulties. Cognitive psychologists define motivation in terms of two elements: on the one hand, the need and desire for change, on the other, the evaluation of the goal's attainability. Motivation is based on past experience: the feelings of powerlessness and the lack of prospects demotivate the adolescent from achieving the desired changes and offset internal motivation. We can speak of a "motivational career", in which the subjective feelings of monitoring successfulness and self-efficiency are reflected (Stauber, Pohl, Walther, 2007). Although the feelings of the motivational career are subjective, they are based on objective and structural features, so that motivation always reflects structurally-conditioned social inequalities - access to types of experience that would foster internal motivation and strengthen the feelings of self-efficiency in the adolescent (Stauber, Pohl, Walther, 2007).

These new findings are also important for working with adolescents with problems. From the point of view of social pedagogy, it is necessary that the help process is founded on and informed by the needs and interests of the adolescents. This takes place through games, creative design, photography, physical activity, all of which serve to increase the awareness of needs and experiences (Heiner 2004). Similarly, participation is based on the adolescent's capability to cooperate in shaping his everyday life, with his wishes, needs and motives serving as input for the way of life at the institution. This is the only way that the adolescent can gain the experience of being in control of his own decisions, of being able to creatively influence both his own development, as well as external factors.

In her work, Maja Heiner (2004) stresses that in order for them to be attained, the goals set out for the adolescent in the process of providing aid should be set in a concrete, specific, attractive, measurable, realistic and temporally defined manner. All too often the desired changes are defined too abstractly (e.g. "increased level of independence"), or the definition is negative, where the goal is something the individual should not do (e.g. "stop using drugs").

On the basis of the findings concerning motivation, it is essential that we bring the unconscious needs and wishes of the individual to the surface in the initial phase of providing help. This can be done using different techniques, such as exploring the imagination and visualization. In this phase, setting out activities would be too sudden and could conceal the individual's actual needs, desires and interests. Only when we are certain that we have uncovered the real needs of the adolescent (taking into account the body language), can we - together with the adolescent - ascertain concrete, attractive, real and temporally defined goals. On the basis of a biographical approach in help planning, where the starting point is the adolescent's own understanding and experience of life, it becomes necessary for the forms of aid to be more flexible and focus on the individual's specific resources, needs and motives. A real comprehension of an individual's biography, his experiences and explanations of social reality, signifies a departure from standardized and ready-made forms of help and a move towards participationoriented help, based on dialogue and agreement.

\section{References}

Beck, U. (1986). Risikogesellschaft. Auf dem Weg in eine andere Moderne. Frankfurt am Main: Suhrkamp.

Bitzan, M. \& Bolay, E. \& Thiersch, H. (2006). Die Stimme der Adressaten: Empirische Forschung über Erfahrungen von Mädchen und Jungen mit der Jugendhilfe. München: Juventa.

Böhnisch, L. (1999). Abweichendes Verhalten. München: Juventa.

Daigler, C. (2008). Biografie und Sozialpädagogische Profession. Eine Studie zur Entwicklung beruflicher Selbstverstaendnise am Beispiel der Arbeit mit Mädchen und jungen Frauen. München: Juventa.

Glinka, H. J. (1998). Das Narrative Interview. Muenchen: Juventa.

Heiner, M. (2004). PRO-ZIEL Basisdiagnostik. Ein prozessbegleitendes, zielbezogenes, multiperspektivisches und dialogisches Diagnoseverfahren in Vergleich. In: Heiner, M.(ed.), Diagnostik und Diagnosen in der Sozialen Arbeit, 218-239. Berlin: Eigenverlag des Deutschen Vereins für öfentliche und private Fürsorge.

Herriger, N. (2002). Empowerment in der Sozialen Arbeit. Berlin: Kohlhammer.

Keupp, H. (2006). Identitätkonstruktionen: Das Patchwork Identitäten in der Spätmoderne. Berlin: Rohlwolt. 
Schefold, W. (2004). Fallabklärung bei Hilfen zur Erziehung: Das Modell der »versierte Fachkraft«. In: Heiner, M. (ed.), Diagnostik und Diagnosen in der Sozialen Arbeit, 85-98. Berlin: Eigenverlag des Deutschen Vereins für öffentliche und private Fürsorge.

Walther, H. , Axsel, P., Stauber, B. (2007). Subjektorietierte Uebergangsforschung. Rekonstruktion und Unterstuetzung biografischer Uebergaenge junger Erwachsener, München: Juventa.

Schwabe, M. (2008). Methoden der Hilfeplanung, Frankfurt am Main; Internationale Gesellschaft fuer erzieherische Hilfen.

Schwarzer, R. \& Jerusalem, M. (2002). Das Konzept der Selbstwirksamkeitserwartung, Zeitschrift für Pädagogik $44,25-35$.

Stark, W. (1996). Empowerment. Neue Handlungensperspektiven in der psychosoziale Praxis. Freiburg: Lambertus.

Stauber, B. \& Pohl, A. \& Walther, A. (2007). Subjektorientierte Übergangsforschung. Rekonstruktion und Unterstützung biografischer Übergange junger Erwachsener. München: Juventa. 